\title{
Internal-Migration of Chhattisgarh: Socio-Economic aspect
}

\author{
${ }^{1}$ Parvaze A. Lone, ${ }^{2}$ Naseer A. Rather \\ ${ }^{1,2}$ Department of Economics, S.S.L. Jain P.G. College Vidisha ( M.P.) India
}

\begin{abstract}
The present paper assesses the social and economic situation of people living in Chhattisgarh and the factors responsible for their migration to other towns and cities in search of better livelihood and better quality of life. The study of internal migration assumes special importance in any state in the process of development. By its very nature internal migration, that is the movement of people across smaller units within the state, is related to a process of change occurring within the social system. Migration is an important feature of human civilization. It reflects, human endeavor to survive in the most testing conditions both natural and manmade. Migration in India is in existence historically. In Chhattisgarh, counter insurgency measures such as the creation of a popular movement to resist naxalist groups, Salwa Judum, has led to the forcible displacement of people throughout Bhairamgarh, Geedam Bijapur areas, under police and administrative supervision. According to official estimates approximately 15,000 people from 420 villages are living as refugees in temporary camps. People have left behind their cattle and most of their household goods.
\end{abstract}

Keywords: Internal-migration, Salwa Judum, Chhattisgarh.

\section{Introduction}

According to census of India 2001, Chhattisgarh attains the rank of $8^{\text {th }}$ among top ten states for intrastate migration (rural to rural) by last residence. And it was identified that 1,360,501 persons of Chhattisgarh migrated from rural to rural areas which comprises the $69.2 \%$ of total intra-state migration. The report also reflects that in Chhattisgarh both male intra-state migration rate and female intra-state migration rate are more than $10 \%$. However, not all people react in the same way to differences between places. The selectivity influence of migration characterizes the different propensity to migrate for different categories of people. Young people in the working age have a higher propensity to migrate than people in other age groups. Moreover, education is also an important selective factor. High skilled people tend to migrate more than low skilled people (Greenwood, 1997). Gravity Model argues that migration is directly correlated with population size and inversely correlated with the distance between the origin and the destination regions. The migration-prone households in Chhattisgarh are 1.9 percent, in Jharkhand 0.8 percent and 1.3 percent in Orissa. Unlike tribal's, the other social groups, Scheduled Castes and other backward classes, have witnessed an increase in migration. The survey says the number of households, where migration takes place, has increased by a percentage point, meaning more people coming to cities than before. About ten million people $(9,400,000)$ across Chhattisgarh's 18 districts have been severely affected by drought during last year. Among them are 400 people in Pangri village in Rajnandgao district. Rajnandgao was one of the 18 districts that were declared drought-hit by the state government during last year. Now, according to current government disaster management rules, once a district is officially declared drought-hit, the administration has to immediately start a relief and mitigation process. The process includes providing free food, drinking water and also special employment to the affected people. None of this has reached Pangri village. The study therefore, presents some suggestions in tune with the future demands so as to solve the migrational problems of Chhattisgarh.

The name Chhattisgarh is not ancient and has come into popular usage in the last few centuries. In ancient times the region was called Dakshin Kosala. The word Chhattisgarh was popularized during the Maratha period and was first used in an official document in 1975. Chhattisgarh State was carved out of the erstwhile Madhya Pradesh State on $1^{\text {st }}$ November, 2000 and has a total area of 1,35,194 square kilometer comprising of 18 districts, 146 blocks and 19,744 inhabited villages. According to the 2001 Census, the total population of Chhattisgarh is 2.08 crore out of which $79.9 \%$ is rural in nature. The density of population in the State is 130 persons per square kilometer. The State has a predominate ST population accounting for $31.8 \%$, SC's $11.6 \%$ and the rest other communities including Backward Classes.

Migration is a social, economic and universal phenomenon in modern times, through which human being move from one place to another place in pursuit of certain cherished objectives like avenues of better employment, better wages, better working and living conditions, better quality of life and better livelihood. The nature and pattern of migration varies from one social group of migrants to another because of the fact that the rural migrants are not a homogenous group (Mitra and Murayama, 2008). Migration is mostly influenced by Social Structures and pattern of development. Uneven development is the main cause of Migration. Added to it, are the disparities, Inter regional and amongst different socio-economic classes. The landless poor who mostly belong to lower castes, indigenous communities and economically backward regions constitute the major 
portion of Migrants. Under the internal migration, four streams are identified: (a) rural to rural (R-R); (b) rural to urban (R-U); (c) urban to urban (U-U); (d) urban to rural (U-R). In India, during 2001, out of 1,029 million people in the country, 307 million (30\%) were reported as migrants by place of birth. However, this figure was 315 million (31\%) in case of place of last residence. There are two reasons why we believe that the state of Chhattisgarh is a crucial case for furthering our empirical and theoretical understanding of insurgency among indigenous people in general. First, for the past one hundred years Chhattisgarh's southern region has been an important battleground for understanding India's tribal people and their relationship with dominant society. This began with British "anthropologist administrators", such as Eldwin (1988) and has continued to the present day with anthropologist such as Sunder (2001a). Second, Chhattisgarh is the epicenter of the Naxalite insurgency.

\section{Literature Review}

The concept of internal migration now connotes much dimension that varies from daily commuting to nearby places on one hand, to permanent shift of residence to distant places on the other. Internal migration is defined as 'population movement across a political or administrative boundary, which entails a change of usual residence' (Bilsborrow, 1998). The concept of internal migration (from rural to urban) attracted the attention of both academicians and policymakers only after the seminal work of Lewis (1954). The availability of good agricultural land continues to be one of the most powerful economic factors determining the magnitude and direction of population migration. The agricultural unemployment and underemployment, lower agricultural wage and poverty are the major factors pushing labourers towards job opportunities in urban areas, while the availability of employment opportunities, relatively higher wages, better education opportunities, better availability of transportation and infrastructure etc. are the major factors in the rural-urban migration (Harris and Todaro, 1970; Barro \& Sala-i-Martin, 1991; Gupta, 1993; Bhattacharya, 1998; Pekkala and Tervo, 2002; Bhattacharya, 2002; and Joshi \& Lobo, 2003; Andrenko and Sergel, 2003).

Internal migration has greater potential for poverty reduction, meeting the Millennium Development Goals (MDGs) and contributing to economic growth in developing countries than international migration ( Srivastava and Sasikumar, 2004; Deshingkar et al, 2006). The relatively poor and backward states show large population mobility, which is primarily in search of livelihood. The group of variables that can affect internal migration flows is quite broad and is related with the quality of life. All these factors concern public safety, social services, environmental quality, as well as political factors (Adrienko and Guriev, 2003). According to Adrienko and Guriev (2003), people move from poorer and job scarce regions with worse public good provision to areas that are richer and more prospering both in terms of employment prospects and public goods. Therefore in this context, an attempt has been made to examine the socio-economic aspect of migration in Chhattisgarh.

\section{Data and Methodology}

The research paper is based on secondary source of data produced by the State Government, civil society assessments, academic literature, magazines, journals, books, civil registration system, sample registration system and population census. Interaction with people is also reflected in the paper.

Migration is both old and new human practice. There is no place or time, in which migration does not occur. However, the scale, type and implications of migration vary greatly between individuals and societies. Among the four types of migration direction-wise, i.e., rural-to-rural, rural-to-urban, urban-to-rural and urban-to-urban, rural-to-rural migration has been dominant. And with respect to the distance of migration, intra-state migration is predominant.

\section{Gross decadal percentage of intra and inter-state migration of Chhattisgarh (2001)}

Below given, Fig. 1 reveals that in Chhattisgarh the percentage of intra-state male and intra-state female migration is 6.58 and 8.64 respectively. It also shows that the percentage of inter-state male and inter-state female migration is 2.22 and 2.38 respectively. Thus the below empirical analysis shows that in both the cases of intra-state migration and inter-migration of Chhattisgarh the percentage of females is higher than the males. 
Fig.1

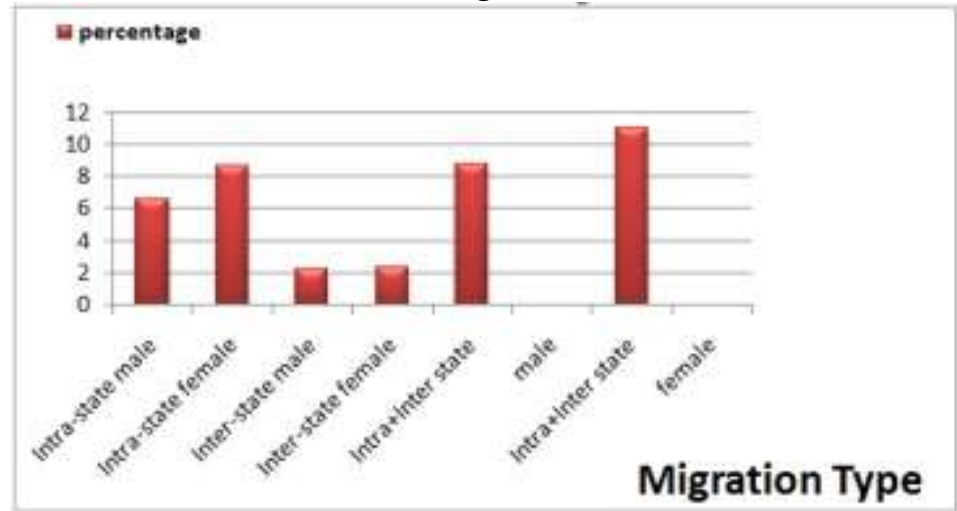

Source: Census of India 2001

Migration rate: the systematic comparison of migration rate between Chhattisgarh and India shows that in Chhattisgarh migration rate in every respect is higher than the migration rate of India. And the migration rate is classified on the base of sex and area (i.e., rural-urban area). Table 1 show that the migration rate of male and female in urban areas is 330 and 590 respectively, which is higher than the migration rate noticed from rural areas of Chhattisgarh as shown in Fig. 2.

Table 1: Migration rate (per 1000 person) for Chhattisgarh in rural and urban areas with comparison to India.

\begin{tabular}{|l|l|l|l|l|l|}
\hline Chhattisgarh & \multicolumn{2}{l|}{ India } & \\
\hline \multirow{2}{*}{ Sex } & Migration Rate & \multirow{2}{*}{ Sex } & & \multicolumn{2}{l|}{ Migration Rate } \\
\cline { 2 - 3 } \cline { 6 - 7 } & Rural & Urban & & Rural & Urban \\
\hline Male & 70 & 330 & Male & 54 & 259 \\
\hline Female & 531 & 590 & Female & 477 & 456 \\
\hline Male+Female & 295 & 452 & Male+Female & 261 & 354 \\
\hline
\end{tabular}

Fig.2

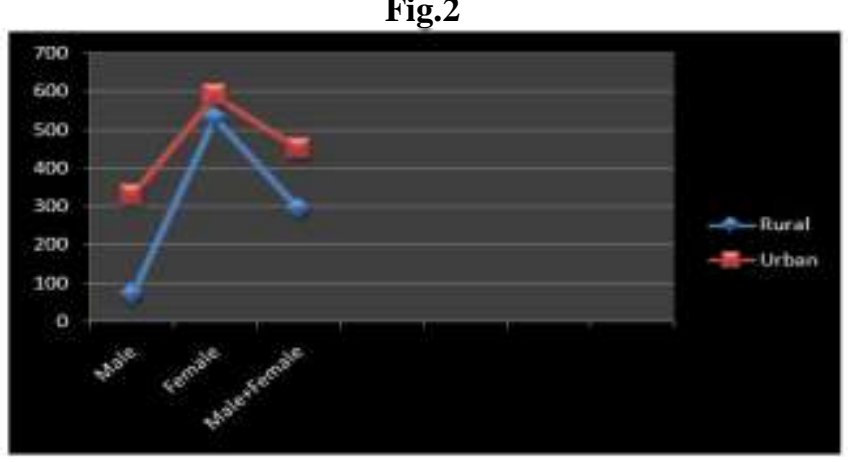

\section{Distribution of Migrants by destination in Chhattisgarh.}

In Chhattisgarh most of the migration is short distance migration i.e., within the state. However, this kind of short distance migration is for more than a month. Almost one third of them also report migrating for more than three months. And during the distribution of migrants by destination in Chhattisgarh, the percentage of migrants inside the block (outside the village) comprises the $45 \%$ and the migrants outside the district (within the state) constitutes only $3 \%$ of total migrants in Chhattisgarh as shown in pie diagram (Fig. 2.) 


\section{Fig.2}

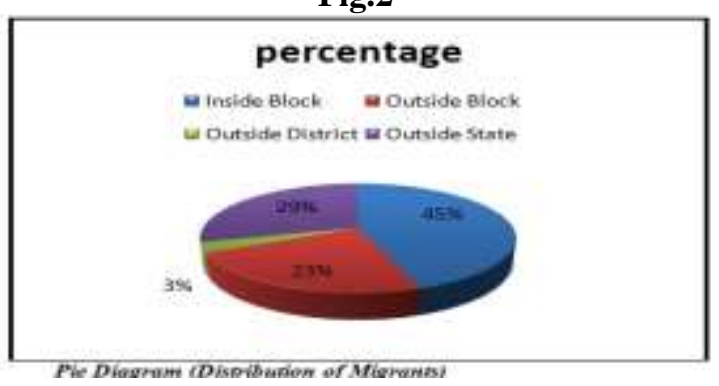

\section{Suggestions}

- National governments have the primary responsibility for the security and well-being of all displaced people on their territory.

- Chhattisgarh state government should take all necessary and appropriate measures to end unlawful Salwa Judum activities.

- Chhattisgarh state government should establish conditions for and facilitate the safe return or resettlement of camp residents and other displaced persons who voluntarily choose to return to their villages.

- The Maoist party should immediately end abuses-such as killings, threats extortion, and the indiscriminate use of landmines and IEDs- against civilians, individuals who have participated in Salwa Judum, camp residents who served as SPOs, and police informers.

\section{Conclusion}

In Chhattisgarh, leftist extremist groups, commonly referred to as Maoists or Naxalities, have significantly increased insurgent activities during the past few years. No estimate of the number of people displaced as a result of the insurgency in central India is available, but anecdotal information suggests that thousands of villagers have been displaced either as a result of government mobilization against the insurgent groups or because they feel Naxalite violence. In Chhattisgarh, approximately 15,000 people from 420 villages have fled to temporary camps. People have left behind their cattle and most of their household goods. Displacement is reportedly continuing while more police and Para-military stations are being set up. Another article says 7,000-10,000 people fled to camps protected by the police to avoid Naxalite retaliation they had joined the Salva Jodum movement.

India is party to the International Convenant on Economics, Social and Cultural Rights (ICESCR) and has an obligation to "recognize the right of everyone to an adequate standard of living for himself and his family, including adequate food, clothing and housing, and to continuous improvement of living conditions." The ICESCR also requires states to respect the rights of all individuals without discriminating against them on the basis of "race, colour, sex, language, religion, political or other opinion, national or social origin, property, birth or other status."

\section{References}

[1] Andrienko, Yuri, Guriev, Sergei (2003). Determinants of Interregional Mobility in Russia: Evidence from Panel Data, Economics of Transition, Vol. 12, pp 1-2.

[2] Barro, Robert J. and Xavier Sala-i-Martin (1991). Convergence Across States and Region, Brookings Papers on Economic Activity, no. 1, pp 107-182.

[3] Battacharya, P.C. (1998). The Informal sector and Rural-to-Urban Migration: Some Indian Evidence, Economic Political Weekly, May 23.

[4] Chelladurai A. "Causes of rural urban migration" (2009). Kurukshetra.

[5] Gupta, M. (1993). Rural-urban Migration, Informal sector and Development Policies: A Theoretical Analysis, Journal of Development Economics, Vol. 41, No. 1, pp 137-151

[6] Joshi G.V. and N Lobo (2003). Rural-urban migration and rural unemployment in India. New Delhi: Mohit.

[7] Lewis, A. (1954). Economic Development with unlimited supplies of labour, Manchester School of Economic and Social Studies, May.

[8] Mitra, A. and M. Murayama (2008).Rural to Urban Migration: A District Level Analysis for India, IDE discussion paper no. 137.

[9] Pekkala, S. and Hannu Tervo (2002). Unemployment and Migration: Does Moving Help?, The Schandinavian Journal of Economics, Vol. NO. 4, pp 621-639.

[10] Potdar B.R. "Labour and industrial law in Madya Pradesh / Chhattisgarh" (2008). Wadhwa \& Company, Law Book sellers \& publisher, 27 M.G. Road, Indore (M.P.)

[11] Eldwin, Verrier. 1988. The Tribal World of Verrier Elwin. New Delhi, India: Oxfor University Press.

[12] Sunder, Nandini, (2001). "Debating Dussehra and Reinterpreting Rebellion in Bastar District, Central India." The Journal of the Royal Antropological Institute 7(1):19-35.

- Human Rights Watch interviews with B. Shafiullah, divisional forest officer of Bhadrachalam, December 7, 2007.

- International covenant on Economic, Social and Cultural Rights (ICESCR), art. 11.1, art. 2.1. 